\title{
Dynamic role of LMW-hyaluronan fragments and Toll-like receptors 2,4 in progression of bleomycin induced lung parenchymal injury to fibrosis
}

\author{
Apoorva Pandey ${ }^{1,2}$, Ritu Kulshrestha ${ }^{1 *}$ (i) and Surendra Kumar Bansal ${ }^{2}$
}

\begin{abstract}
Background: Pulmonary fibrosis (PF) is a progressive and lethal lung disease of elderly whose incidence has been increasing following the Covid-19 pandemic caused by severe acute respiratory syndrome corona virus 2 (SARSCoV-2). PF immunopathogenesis involves progressive alveolar epithelial cell damage, release of damage-associated molecular patterns (DAMPs), and extracellular matrix (ECM) injury. We assessed the dynamic role of LMWhyaluronan (LMW-HA) as DAMP in initiation of host immune TLR-2,4 responses and as determinant in progression of ECM injury to fibrosis. Male Wistar rats were divided into Group I (saline control, $n=24$ ) and Group II (intratracheal bleomycin, $7 \mathrm{U} / \mathrm{kg} / \mathrm{animal}, n=24$ ). Animals were euthanized on $0,7,14$, and 28 days. The time course of release of LMW-HA, TLR-2,4 mRNA and protein levels, and NF-KB-p65 levels after bleomycin injury were correlated with the development of parenchymal inflammation, remodelling, and fibrosis.

Results: Acute lung injury caused by bleomycin significantly increases the pro-inflammatory LMW-HA levels and elevates TLR-2,4 levels on day 7. Subsequently, TLR-2 upregulation, TLR-4 downregulation, and NF-KB signalling follow on days 14 and 28. This results in progressive tissue inflammation, alveolar and interstitial macrophage accumulation, and fibrosis.

Conclusions: LMW-HA significantly increases in PF caused by non-infectious and infectious (Covid-19) etiologies. The accumulating HA fragments function as endogenous DAMPs and trigger inflammatory responses, through differential TLR2 and TLR4 signalling, thus promoting inflammation and macrophage influx. LMW-HA are reflective of the state of ongoing tissue inflammation and may be considered as a natural biosensor for fibrotic lung diseases and as potential therapeutic targets.
\end{abstract}

Keywords: Pulmonary fibrosis, Toll-like receptor 2, 4, LMW-hyaluronan, NF-KB

\section{Background}

Pulmonary fibrosis is a progressive lung disease characterized by aberrant tissue repair, excessive accumulation of extracellular matrix (ECM), and scarring. It is a recognized sequelae in genetically predisposed individuals undergoing age-related fibroproliferative diseases. It

\footnotetext{
* Correspondence: ritukumar71@yahoo.com

'Deparment of Pathology, V.P. Chest Institute, University of Delhi, Delhi 110007, India

Full list of author information is available at the end of the article
}

arises from repetitive sub-lethal insults caused by oxidative stress, radiation, chemotherapeutic agents, etc. These varied etiologies show common underlying pathogenesis, alveolar epithelial cell (AEC) injury, epithelialmesenchymal transition (EMT), and persistent ECM production [1]. Abnormal hyperactive and dysregulated innate immune mechanisms are initiated as a consequence of release of inflammatory cytokines; IL-1 $\beta$, IL-6, and TNF- $\alpha$ "cytokine storm" and result in (i) acute lung epithelial injury, (ii) release of DAMPs such as low 
molecular weight-hyaluronan (LMW-HA), heat-shock proteins, high mobility group box protein-1 (HMGB1), etc., (iii) induction of HA synthase 2 (HAS2) in endothelium, lung alveolar epithelial cells, and fibroblasts [2], (iv) dysregulated release of matrix metalloproteinases and ECM remodelling, (v) acute respiratory disease syndrome (ARDS), (vi) epithelial-mesenchymal transition, and (vii) pulmonary fibrosis. The availability of only two antifibrotic drugs till date has highlighted the need to identify the potential clinical and laboratory biomarkers that can predict the subgroup of patients that are going to deteriorate or develop lung fibrosis.

The ongoing Covid-19 pandemic caused by severe acute respiratory syndrome corona virus 2 (SARS-CoV2) has further increased the occurrence of pulmonary fibrosis since 2020. Diffuse alveolar damage (DAD) caused by SARS-CoV-2 can progress to fibrosis even after virus clearance [3]. Hyaluronan (HA), a highly hygroscopic ECM molecule with the ability to absorb water up to 1000 times its molecular weight, is found in lung alveoli in severe Covid-19 and can promote edema [4]. Since the hyaluronan in cadaveric COVID-19 lung tissue comprises low molecular weight fragments [5], recent studies have suggested estimation of serum and sputum levels of $\mathrm{HA}$ at admission to distinguish critically ill patients with Covid-19 infection [5, 6] as well as prove to be a potential therapeutic target [7].

The ECM comprises of fibrous proteins, collagen and elastin, residing in a milieu of glycoproteins, proteoglycans, glycosaminoglycans, growth factors, cytokines/chemokines, proteases, etc [8]. ECM contributes as an active or passive player to diverse cellular processes; differentiation, proliferation, adhesion, migration, and apoptosis [9]. ECM disruption releases hyaluronidases [10], reactive oxygen species [11], and degrades endogenous HA into LMW-HA and HMW-HA fragments $[12,13]$. These HA fragments are recognized by cell surface receptors; TLR-2,4, CD44, CD168, layilin, RHAMM [14-18], on the basis of their size and correlate with nature and extent of injury. The LMW-HA vary from a few disaccharides up to over $700 \mathrm{kDa}$ [19] and function as pro-inflammatory DAMPs [20], while the high molecular weight HA (HMW-HA) (>5000 kDa) signal the resolution of inflammation and injury $[14,21]$. Therefore, the type of HA fragments (HMW/LMW) predominating in the tissue after injury act as natural biosensors for the state of tissue integrity [22]. The HA fragments differentially trigger an inflammatory immune response during acute lung infection, and chronic injury/repair [23]. Elevated LMW-HA levels have been reported in sputum of Covid-19 patients [5] and in bronchoalveolar lavage (BAL) fluid of asthma, sarcoidosis, ARDS [24], alveolar proteinosis, IPF patients [25]. BALF elevation of $\mathrm{HA}$ is associated with local lung injury while raised levels of HA in blood are indicative of both local lung injury and sequential organ failure. Thus, suggesting the potential utility of HA estimation in identifying local and systemic organ dysfunction in acute respiratory distress syndrome (ARDS) patients [24].

The present study focuses on the pathogenetic pathway of progression of lung tissue inflammation to fibrosis after release of LMW-HA. Elevated LMW-HA release pro-inflammatory cytokines, IL-1 $\beta, 6$, TNF- $\alpha[26$, 27], and chemokines and facilitates leukocyte access to the injury site.This results in cell proliferation [28], migration [29], dendritic cell activation [17], and sterile inflammation [30]. During stage of chronic inflammation, LMW-HA transcribes matrix metalloproteinases (MMP$1,3,9,10,13)$, collagen, and cytokines, TGF- $\beta$, IL-12, and IGF-I [30-32], resulting in attenuation or progression of ECM remodelling. Further, the LMW-HA fragments act as endogenous ligands for Toll-like receptor (TLR-2 and TLR-4) leading to lung inflammation and injury [14]. LMW-HAs engage TLR-2 and activate the macrophage inflammatory response [28]. On the other hand, LMWHAs engage TLR-4 and protect type-II AECs against oxidant-mediated injury. TLR-4 induction maintains appropriate anti-apoptotic response [33] leading to AEC self-renewal and limiting the extent of fibrosis [34]. The ECM participates in progressive fibrotic scarring of lung by (i) activating a profibrotic feedback loop [35], (ii) abnormal ECM cross-linking resulting in enhanced fibroblast growth and preventing normal ECM turnover in IPF [36]. However, the specific ECM-HA-induced TLR signalling resulting in progression of fibrosis continues to remain an enigma [37].

We propose that the differential host immune response to ECM injury and LMW-HA fragments is the critical determinant of epithelial injury/repair processes outcome after both infectious and noninfectious injurious stimuli. These generate feedback signals, leading to either (i) alveolar macrophage priming, increased TLR-2/4 ratio, basal nuclear factor-kappa B (NF- $\mathrm{kB}$ ) activation, inflammation, and progression of parenchymal fibrosis, or (ii) reducing oxidative stress, decreased TLR-2/4 ratio, type-II AEC protection, and renewal and repair of lung injury. We elaborate the differential activation of TLRs-2,4 and macrophage influx during bleomycin-induced parenchymal remodelling.

\section{Methods}

\section{Chemicals}

Bleomycin sulfate (Bleocip, Cipla), ketamine hydrochloride, xylocaine, anti-goat-IgG (SAB3700288, Sigma Life Science), TLR-2 (Sc-10739, Santa Cruz, USA), TLR-4 (Sc-16240, Santa Cruz), CD-68 (ab125212, Abcam), NFкB-p65 (Sc-109, Santa Cruz), ExtrAvidin ${ }^{\circledR}$ Peroxidase 
(Extra-2,3, Sigma), NovaRED (SK-4800, Vector labs, USA), Meyer's hematoxylin, TRIzol $^{\circ}$ (Invitrogen 15596018), chloroform, isopropanol, MMLV (M0253S, NEB), RNase (M0314, NEB), dNTPs (N0447S, NEB), random primers (S1330S, NEB), SYBR Green (S4438, Sigma), protease inhibitor (Sigma), hyaluronan quantikine ELISA (LMW-HA < 35-950 kDa, DHYAL0, R\&D Systems, USA), and Lamin-A/C (612162, BD Biosciences, India) were used.

\section{Animals}

Male Wistar rats $(150-250 \mathrm{~g}, n=48)$ were obtained from the animal house, V.P.Chest Institute. The experimental protocol was approved by institutional animal ethical committee and written consent for use of animals was obtained from IAEC. The animals were divided into two groups, group I: saline control, group II: bleomycin. Both the groups contained 6 animals on each day $0,7,14$, and 28 . Animals were provided with standard rodent diet and water ad libitum. Animal care was as per guidelines laid down by Indian National Science Academy, New Delhi. The experiments were performed in the Animal house of the V.P. Chest Institute. No randomization method and strategy control potential confounders were used.

\section{Induction of lung fibrosis}

Animals were anesthetized with ketamine hydrochloride ( $50 \mathrm{mg} / \mathrm{kg}$-b.w, I.M) and local anesthesia with $1 \%$ lignocaine. The skin was incised under aseptic precautions and trachea was exposed. In control animals, $100 \mu \mathrm{l}$ of $0.9 \%$ normal saline was instilled intratracheally. Experimental animals received single intratracheal instillation of bleomycin ( 7 units/kg-bw) in $100 \mu \mathrm{l}$ saline, as previously described [38]. After instillation, incision was sutured and betadine and antibiotic ointment was applied. Animals were euthanized $0,7,14$, and 28 days after intratracheal bleomycin administration, by using overdose of ketamine hydrochloride. The lungs were ligated at the trachea and removed en bloc. The lungs were immersed in $10 \%$ neutral buffered formalin for fixation and processed through a graded series of alcohols and xylene prior to paraffin embedding. Five-micrometer sections of the lungs were deparaffinized and stained with hematoxylin and eosin stain. The time course of release of LMW-HA fragments, TLR-2,4 mRNA and protein, NF-kB-p65, macrophage influx, and CD68 expression after bleomycin injury were correlated with development of parenchymal inflammation and fibrosis.There were no exclusions in analysis of control and experimental groups.

\section{LMW-HA}

LMW-hyaluronan levels $(<35-950 \mathrm{kDa})$ were quantitated by using the quantitative sandwich enzyme immunoassay technique (Hyaluronan Quantikine ELISA Kit DHYAL0, R\&D systems). Lung tissue $(500 \mathrm{mg}$ ) was homogenized in lysis buffer (0.5\% TritonX-100, 150 $\mathrm{mMNaCl}, 15 \mathrm{mM}$ Tris, $1 \mathrm{mM} \mathrm{CaCl} 2,1 \mathrm{mM} \mathrm{MgCl}_{2}, \mathrm{pH}$ $7.40)$ and centrifuged at $12,000 \mathrm{~g}\left(4^{\circ} \mathrm{C}, 20 \mathrm{~min}\right)$. Fiftymilliliter aliquots of supernatant sample were pipetted into the pre-coated wells. After binding and washing steps, $100 \mu \mathrm{L}$ of enzyme-linked polyclonal antibodies specific for LMW-hyaluronan was added to the wells. The plates were incubated for $2 \mathrm{~h}$ at $37^{\circ} \mathrm{C}$. The unbound antibody-enzyme reagent was removed by washing and a chromogen substrate solution was added. The plates were incubated at room temperature for $30 \mathrm{~min}$. The reaction was terminated with $100 \mu$ l of diluted hydrochloric acid solution per well and read at $450 \mathrm{~nm}$ in an ELISA reader.

\section{Gene expression}

Total RNA was extracted from lung using guanidinium thiocyanate-phenol-chloroform extractionand reversetranscribed to cDNA. cDNA was amplified: PCR activation $\left(95^{\circ} \mathrm{C}, 5 \mathrm{~min}\right)$; 35 cycles of denaturation @ $95{ }^{\circ} \mathrm{C}$ (30 s), annealing @ $60{ }^{\circ} \mathrm{C}(35 \mathrm{~s})$, extension @ $72{ }^{\circ} \mathrm{C}(30$ s); final extension @ $72{ }^{\circ} \mathrm{C}(7 \mathrm{~min})$. Quantitative realtime PCR was performed using Mastercycler, Eppendorf, and primers: TLR-2: Forward-Primer-ATGGCAGCTC CAGGTCTTTC, Reverse-Primer-TTCCGCTGGACTCC AATGTC, TLR-4: Forward-Primer-TCAAGCCCAA GCCTTTCAGG, Reverse-Primer-TTCTCCCAAGATC AACCGATGG, $\beta$-actin: Forward-Primer-GACCTTCA ACACCCCAGCCA, Reverse-Primer-GTCACGCACG ATTTCCCTCTC. Relative gene expression was calculated, using $\Delta \Delta \mathrm{Ct}$ method.

\section{TLR protein}

Immunohistochemistry was performed on lung sections which were deparaffinized and rehydrated through graded alcohols. Endogenous peroxidase was quenched by treatment with $0.3 \%$ hydrogen peroxide in methanol for $3 \mathrm{~min}$. Sections were incubated with the primary antibodies-TLR-2, TLR-4, CD68. The bound antigen was then visualized with the avidin-biotinylated peroxidase technique using DAB substrate. Sections were counterstained with Harris' hematoxylin, dehydrated, cleared in xylene, and mounted with DPX. Immunostaining was quantified using a Nikon-90i microscope and NIS-Ar image analysis software as per previously described method [39]. Briefly, 10 fields ( $\times 40)$ were randomly selected and chromogen-positive cells measured. The intensity of positively stained cells was subtracted from 250 (maximum intensity of RGB image) to obtain reciprocal intensity which is directly proportional to protein expression. 


\section{NF-KB-p65}

NF-kB-p65 was assessed in lung tissue nuclear extracts by Western blot as per previously described method [40]. Then, $200 \mathrm{mg}$ tissue was homogenized in buffer-A (150 mM NaCl, $0.5 \mathrm{mM}$ PMSF, $1 \mathrm{mM}$ EDTA, $10 \mathrm{mM}$ HEPES, $0.6 \%$ NP-40). The nuclear pellet was resuspended in solution-B (25\% glycerol, $20 \mathrm{mM}$ HEPES, 420 $\mathrm{mM} \mathrm{NaCl}, 1.2 \mathrm{mM} \mathrm{MgCl}_{2}, 0.2 \mathrm{mM}$ EDTA, $0.5 \mathrm{mM}$ PMSF, $0.5 \mathrm{mM}$ DTT). Total nuclear proteins were quantified using Bradford assay [41]. Proteins were resolved on 12\% SDS-PAGE and transferred onto PVDF membranes. Membranes were blocked with 5\% skimmed milk in TBST buffer and incubated with $10 \mu \mathrm{l}$ of primary antibodies (1:1000), NF-kB-p65, and laminin-A/C (1:1000) for $2 \mathrm{~h}$ at room temperature. Membrane was washed thrice with TBST and then incubated with biotinylated secondary antibody (1:2000) of goat anti-Rabbit IgG for $2 \mathrm{~h}$. Following washing, membrane was incubated with extravidin (1:5000) for $2 \mathrm{~h}$ and visualized using NovaRED in Gel documentation system (Bio-Rad). Membrane was then blocked again with 5\% skimmed milk in TBST at $4{ }^{\circ} \mathrm{C}$ overnight and re-probed with housekeeping protein (Lamin-A/C, 612162, BD Biosciences, India). Densitometry was performed using Image lab software-2.0, and values were normalized to Lamin-A/C.

\section{Statistics}

Statistical analysis was done by GraphPad prism-5.0, using one-way ANOVA with Newman Keule's post hoc test and expressed as Mean \pm SEM (standard error of mean). $P$ value $<0.05$ was considered significant.

\section{Results}

\section{Bleomycin-induced LMW-HA}

Bleomycin-induced lung injury is characterized by HA fragmentation that act as endogenous ligands for TLRs [17]. Other endogenous ligands of TLRs include fibrinogen [42], surfactant protein-A [43], extradomain-A of fibronectin [44], heparan sulfate [45], and HMGB-1 [46]. These ligands induce innate and adaptive immune response through induction of costimulatory molecules in antigen-presenting cells [47] and propagate parenchymal inflammation [48

The present study shows significant increase in levels of LMW-HA fragments in lung tissue on day 7 (322 \pm $14.0 \mathrm{pg} / \mathrm{mL}$ ), after bleomycin as compared to control $(162.2 \pm 3.79 \mathrm{pg} / \mathrm{mL})$ (Fig. 1). LMW-HA increased persistently up to day $14(264 \pm 16.65 \mathrm{pg} / \mathrm{mL})$ and decreased in fibrotic phase (day 28, $128 \pm 13.15 \mathrm{pg} / \mathrm{mL}$ ). This is similar to previous study by Teder et al. in mouse model, who observed massive accumulation of HA (5.4 $\times 10^{5} \mathrm{MW}$ ), on day 7 , in alveolar spaces and interstitium, following bleomycin, as compared to control (14.4 $\left.\times 10^{5} \mathrm{MW}\right)$. They reported that a vast majority of HA fragments are cleared from the lung within 14 days after injury and impaired clearance is followed by collagen deposition and fibrosis [49]. LMW-HA clearance occurs after their internalization [50] by receptors such as TLR2, TLR4, and CD4 [51, 52]. Persisting HA has proinflammatory effects and perpetuates tissue inflammation and injury [53]. In a recent autopsy study, hyaluronan staining confirmed prominent HA exudates in alveolar spaces of Covid-19 lungs, suggesting its role in ARDS caused by SARS-CoV-2 [7].

\section{Bleomycin-induced lung inflammation}

Bleomycin causes oxidative damage to AECs DNA, leading to an initial neutrophil influx, followed by infiltration of lymphocytes and macrophages from day 3 onwards [54]. In the present study, we demonstrated chronic interstitial inflammation comprising of lymphocytes and macrophages on days 7 and 14 after bleomycin (Fig. 2d, e) as compared to control (Fig. 2a, b). This was associated with increase in LMW-HA (Fig. 1). This is similar to previous studies, where LMW-HA expression coincides with recruitment of circulating monocytes [55] and early macrophage accumulation at site of lung injury

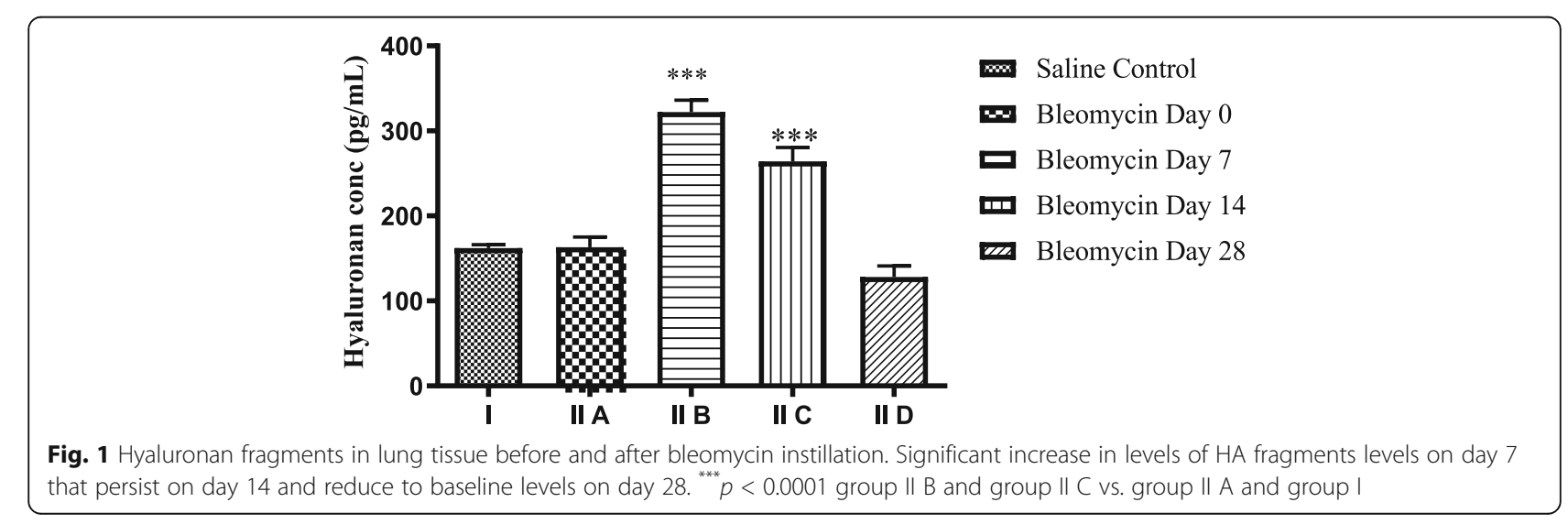




\section{Saline Control}

(A)

\section{Bleomycin}

Day 0 (B)

Day 7 (C)

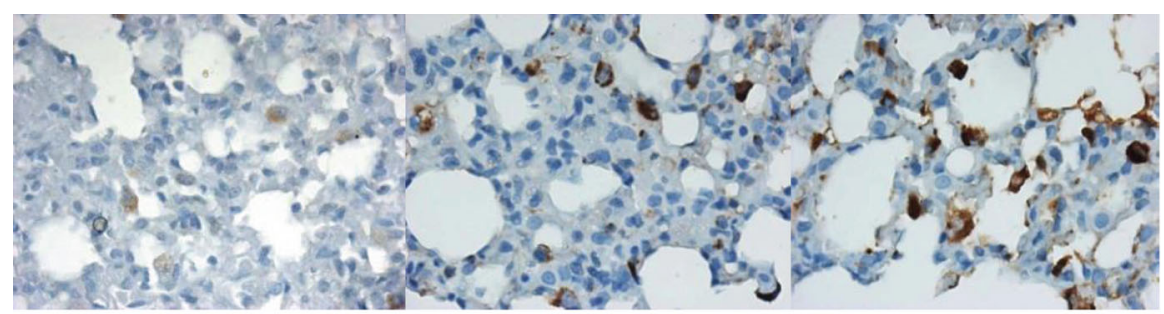

Bleomycin Day 14 (D)

Day $28(\mathrm{E})$

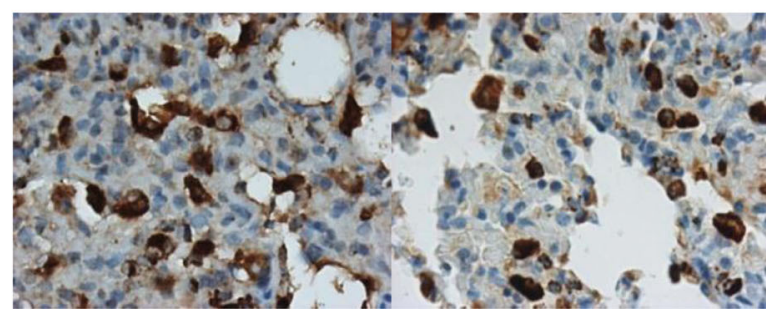

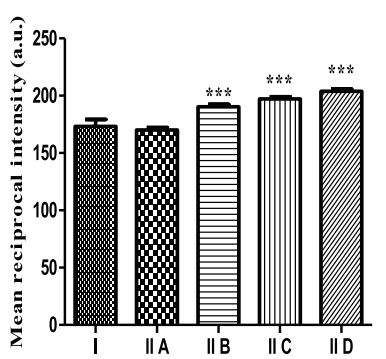

(F)

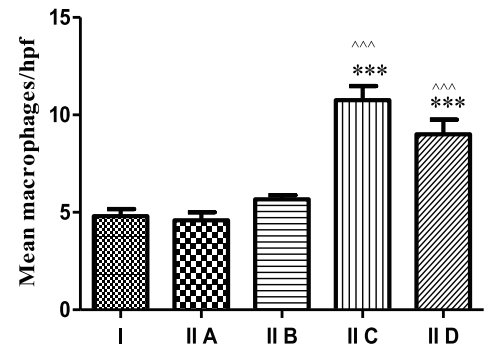

(G)

Fig. 2 a Macrophage infiltration in lung parenchyma before and after bleomycin instillation. Weak CD68 positive macrophages were seen in saline control lungs and on day 0 bleomycin $(\mathbf{a}, \mathbf{b})$ by immunohistochemistry. $\mathbf{c}$ Note the increase in CD68 expression and influx of macrophages on day 7 after bleomycin instillation (c) that persists up to days 14 and 28 (d, e). $\mathbf{f}$ Quantification of CD68 protein expression by macrophages shows significant increase in CD68 protein intensity from day 7 onwards up to day $28 .{ }^{* * *} p<0.0001$ group || B, group || C, group || D vs. group II A, group I. g A significant net influx of macrophages/high power field $(\times 400)$ is seen after bleomycin instillation by morphometry on day 14 that persisted up to day $28 .{ }^{* * *} p<0.0001$ group || C, group II D vs. group II A, group I; ${ }^{\wedge \wedge} p<0.0001$ group $\|$, group II D vs. group II B

[56]. These CD68-positive macrophages localize to perivascular sites of injury on day 7 after bleomycin [57] and undergo proliferation, M1/M2 polarization, and release profibrotic cytokines like TGF- $\beta 1$. TGF- $\beta 1$ activates fibroblasts, causing EMT and ascending grade of parenchymal fibrosis [58]. In the present study, the parenchymal remodelling on day 28 was characterized by reduced cellularity with persistence of macrophages (Fig. 2f) even after LMW-HA levels declined (Fig. 1). LMW-HA and TLR-2,4-induced macrophage macrophage influx and accumulation [14] is suggested to be key component in progression of lung fibrosis [59]. However, LMW-HAs can also stimulate macrophages independently of CD44 and TLR-4 via the TLR-2/
MyD88 pathway [19] leading to IRAK, TRAF6, and NF$\mathrm{KB}$ activation [28]. These accumulating macrophages and their associated hyperactive and dysregulated innate immune response need to be explored as biomarkers of disease activity and progression [38]. The innate and adaptive immune imbalance results in unbridled production of pro-inflammatory cytokines and chemokines and contributes to "cytokine storm" and severity of Covid-19 patients $[60,61]$.

\section{Bleomycin-induced TLR-2 response}

During inflammation, HA fragments differentially engage TLRs, based on their size. HA fragments bind to TLR-2 on alveolar macrophages, trigger NF-kB 
activation, provide a supportive environment for the immune cells, and promote inflammation [62]. On the one hand, the TLR-NF- $k B$ pathway is central in promoting infection-induced lung injury while on the other hand, increased uptake of HA by macrophages can help in reducing inflammation and promoting repair; therefore, the exact role of TLRs, as a friend or foe in pathogenesis of lung fibrosis, remains to be elaborated [63].

In present study, significant increase in TLR-2 mRNA (Fig. 3g, fold change (FC)-3.8, $" p<0.001$ ) and protein expression (Fig. 3c) was seen in AECs, perivascular inflammatory cells, and macrophages, on day 7 , after bleomycin, as compared to control (Fig. 3a). On day 14, TLR-2 mRNA levels remained elevated (Fig. 3g, FC-4.8, $p<0.0001)$ and correlated with its enhanced protein expression in all above cell types (Fig. 3d). The significantly increased TLR-2 mRNA levels on days 7 and 14 correlated with elevated LMW-HA levels on these days (Fig. 1). Upregulated TLR-2 mediates production of TGF- $\beta 1$ and interleukins, IL-6,12,23 $[9,64]$, and initiates the Th2-lymphocyte response [65]. From the resulting chemokine production, M2 macrophage polarization leads to cellular phase of bleomycin-induced pneumonitis [66]. On day 28, TLR-2 mRNA levels decreased as compared to control (Fig. 3g, FC-1.65); however, TLR-2 protein expression persisted in AECs and macrophages (Fig. 3e,f) and was associated with persistent M2 macrophage polarization and progression of tissue fibrosis [67]. HA-TLR2 binding activates NF-kB, MAPKs, p38, and JNK pathways and releases pro-inflammatory and profibrotic cytokines such as interleukin-1, MIP-1, PDGF, and TGF- $\beta 1$ [68]. Previously, our group has demonstrated an increased expression of TGF- $\beta 1$ in type-II AECs, EMT cells, alveolar macrophages, and interstitial fibroblasts from day 7 up to day 35 after bleomycin [69]. Thus, LMW-HA-TLR-2 interactions are not only critical as pro-inflammatory signalling cascade but are also associated with increased TGF- $\beta 1$ expression [69]. Blocking this pathway may attenuate lung inflammation and fibrosis by altering the pulmonary immune microenvironment [70].

\section{Bleomycin-induced TLR-4 response}

LMW-HA are mainly TLR-4 dependent [15] and upregulate CD68 expression in macrophages in a TLR-4dependent manner similar to bacterial lipopolysaccharide [71] and interferon- $\gamma$ [72]. The activated macrophages use $\mathrm{HA}$ as a substrate to aid in migration towards site of injury, and HA binding helps in retaining the activated cells at the sites of inflammation. The SARS-CoV-2 spike protein strongly interacts with the Toll-like receptor 4 (TLR4) pathway producing proinflammatory cytokines such as interleukin-6 (IL-6) and tumor necrosis factor-alpha (TNF- $\alpha$ ) culminating in cytokine storm and multiple organ failure [73]. TLR-4 deficiency increases the inflammatory response elicited by LMW-HA [74] resulting in elevated cytokine and chemokine levels [71], which skew towards a Th2/Th1 response and increased fibrosis.

In the present study, increased TLR-4 mRNA (Fig. 4g, FC-9.4, $\left.{ }^{* x} p<0.001\right)$ and protein expression was seen in AECs, BECs, and macrophages (Fig. 4c) on day 7, after bleomycin as compared to control (Fig. 4a, f). On day 14, TLR-4 mRNA levels decreased (Fig. 4g, FC-2.29, $p=$ ns), while TLR-4 protein expression persisted in AECs, BECs, and macrophages (Fig. 4d) up to day 28 (Fig. 4e). TLR-4 mRNA downregulation correlated with the progression of fibrosis (Fig. 4g, e). TLR-4 protects against oxidant-mediated lung injury by maintaining antiapoptotic responses [75], promoting alveolar stem cell renewal [33] and epithelial self-defense mechanisms through TLR-4-dependent basal activation of NF- $\mathrm{KB}$ [34]. Studies in bleomycin challenged TLR-4 knockout mice have found them to develop stronger inflammatory response [71] with significantly lower type-I collagen mRNA levels as compared to WT mice [76]. The basal TLR-4 activity is critical for resolution of acute and chronic inflammation in pulmonary fibrosis [77]. Our group has previously demonstrated reduction of caveolin-1 levels in bleomycin-instilled lungs [78]. Thus, the TLR-4 mRNA downregulation and accompanying caveolin deficiency [78] contribute to progression to fibrosis during lung injury [79].

\section{Bleomycin induced NF-KB signalling}

$\mathrm{NF}-\mathrm{KB}$ activation is induced by HA fragments [80] and TLR-2,4 activation and results in downstream stimulation of TNF- $\alpha$, TGF- $\beta$, and IFN- $\gamma$ [81]. In the present study, a significant increase of NF-kB-p65 levels were observed from day 7 onwards up to day 28 after bleomycin as compared to control (Fig. 5a, b). This is similar to a previous study which found maximal nuclear translocation of NF- $\mathrm{kB}-\mathrm{p} 65$ on day 7 after bleomycin instillation [82]. NF-кB-p65 upregulation correlated with perivascular lymphocytes and interstitial macrophage infiltration, in the cellular phase. These alveolar macrophages function as the "first responders," resulting in the production of cytokines that then activate NF- $\mathrm{kB}$ in other cell types [83]. After nuclear translocation, the NF- $\mathrm{kB}$ transcriptionally regulates (i) TGF- $\beta 1$ resulting in fibroblast proliferation [84], (ii) matrix metalloproteinases (MMPs) [85] and their inhibitors, tissue Inhibitor of Matrix Metalloproteinases(TIMPs), resulting in protease-antiprotease imbalance, ECM deposition, and matrix remodelling. In the previous study by our group, we have demonstrated that it is the shift in the balance of MMP-9/TIMP-1,3 ratio to less than 1 that primes the inflammatory response and its progression to fibrosis 
Control (A)

\section{Bleomycin}
Day 0
(B)
Day 7 (C)
Day 14 (D)
Day 28 (E)

\section{Alveolar epithelial cells (AECs)}
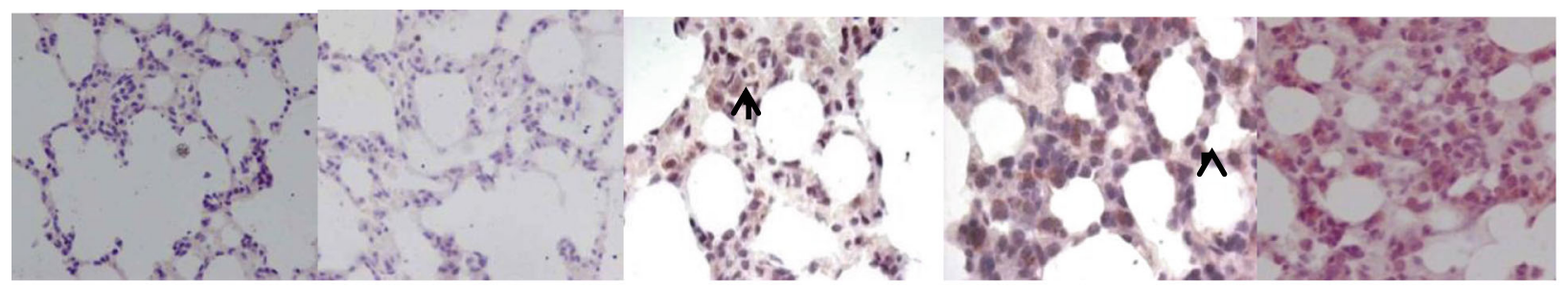

\section{Perivascular inflammatory cells}

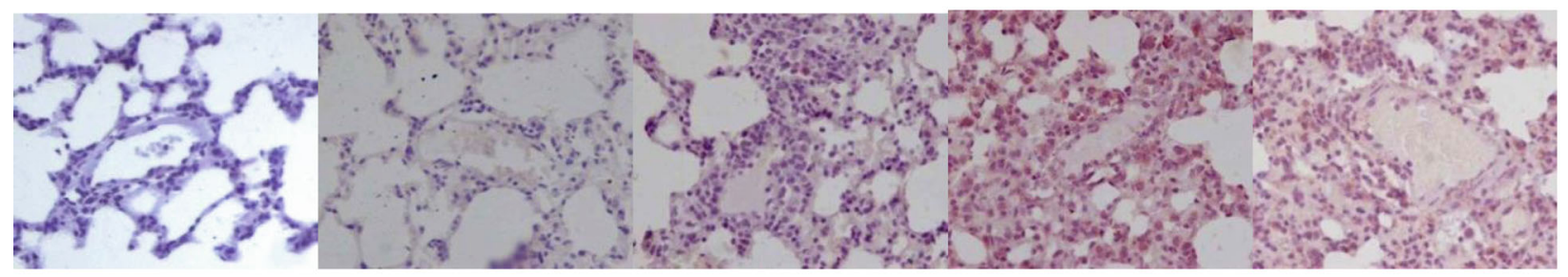

\section{Macrophages}

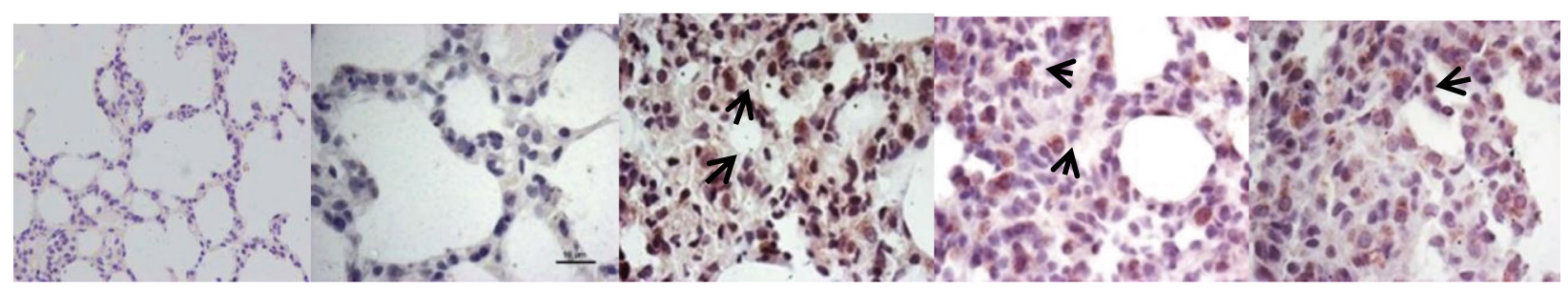

(F)

(G)
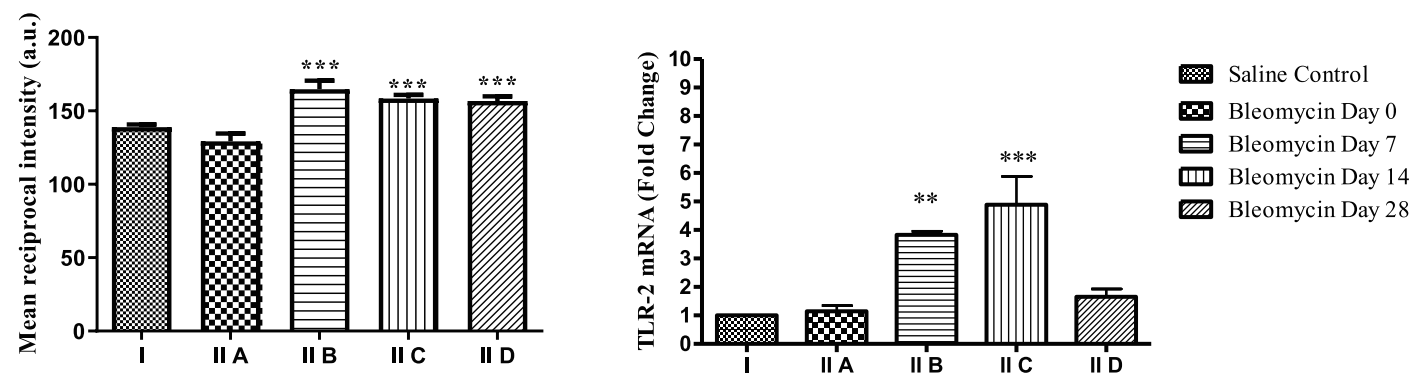

Fig. 3 Toll-like receptor-2 (TLR-2) mRNA and protein expression in lungs before and after bleomycin instillation: As compared to saline control and bleomycin day $0(\mathbf{a}, \mathbf{b})$, on day 7 and 14 after bleomycin instillation, an increased TLR-2 expression is seen in AECs, perivascular inflammatory cells, alveolar and interstitial macrophage by immunohistochemistry (c, d respectively). e On day 28, in fibrotic phase, TLR-2 protein expression persisted in AECs, alveolar and interstitial macrophages of lung parenchyma. $\mathbf{f}$ Quantification of the intensity of TLR-2 protein expression in the lung parenchyma. Significant increase in TLR-2 protein expression was seen from day 7 that persisted up to day 28 . ${ }^{* * *} p<0.0001$ group II B, group II C, group II D vs. group || A and group I. g TLR-2 mRNA levels were significantly upregulated on day 7 and day 14 and returned to baseline on day 28. ${ }^{* *} p<0.001$ group II B vs. group $\| A_{;}^{* * *} p<0.0001$ group \| C vs. group II A 


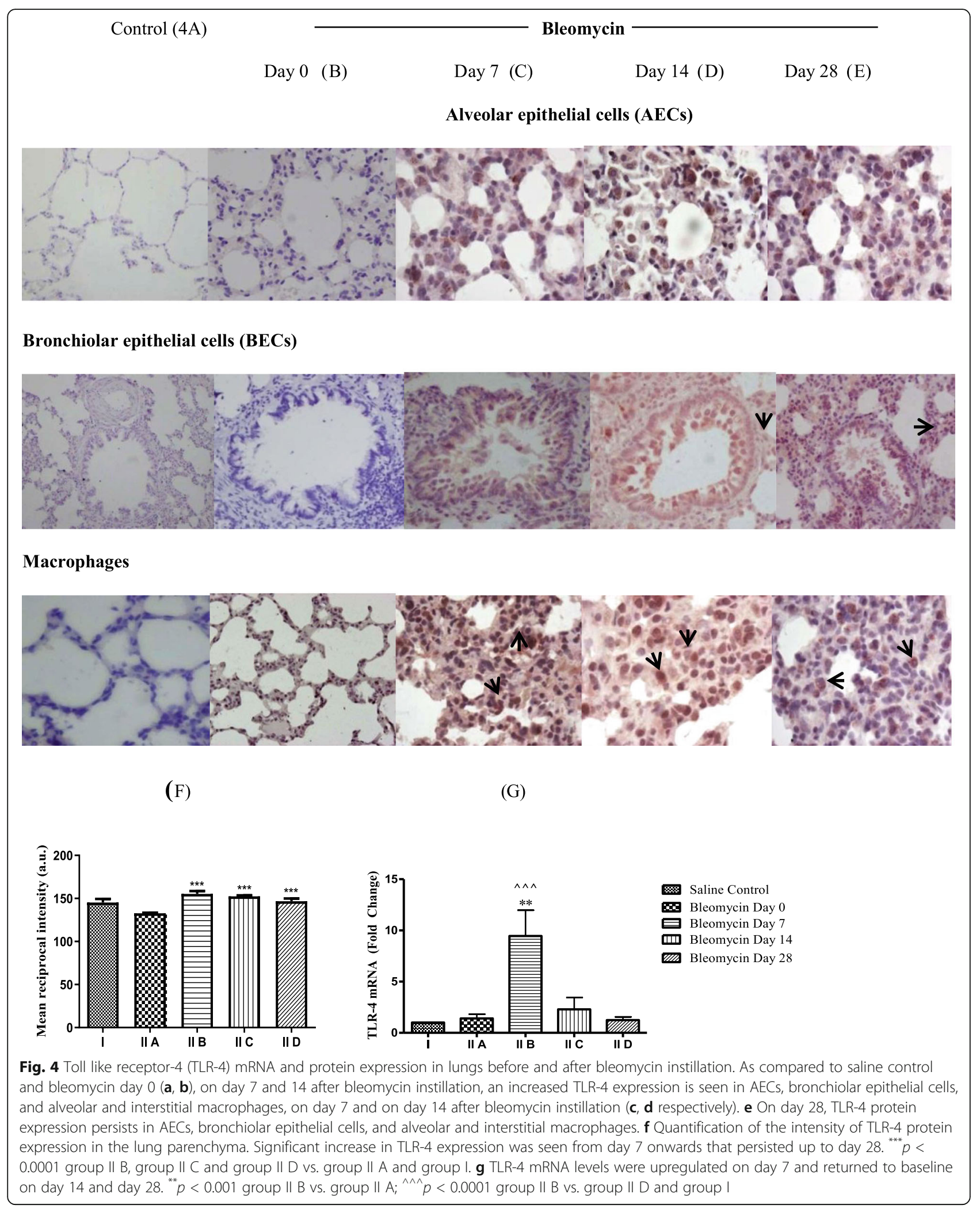


(A)
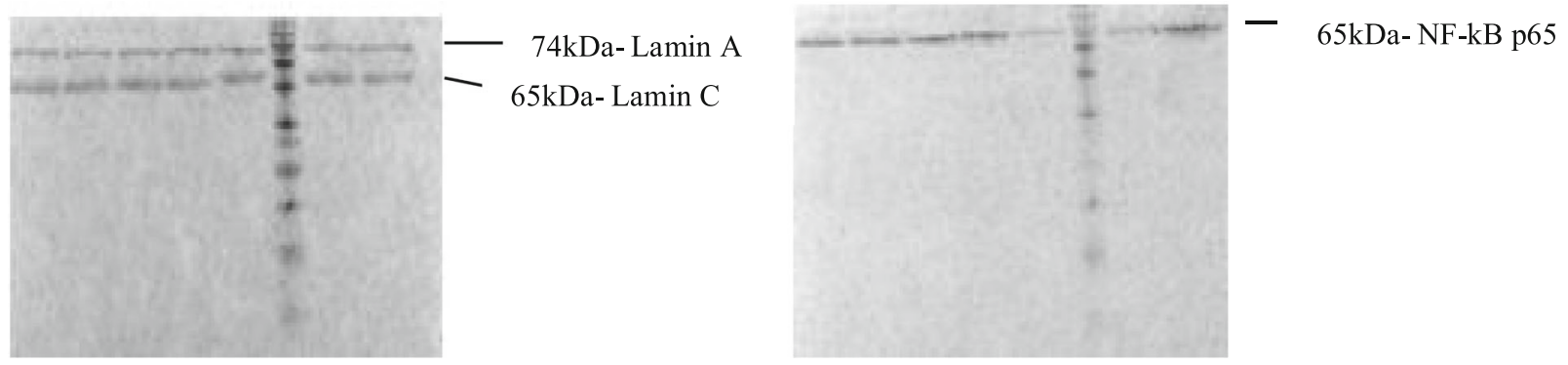

$\begin{array}{llllllll}1 & 2 & 3 & 4 & 5 & 6 & 7 & 8\end{array}$

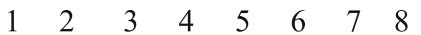

Lane 1\&2-Bleomycin 28D, Lane 3\&4 - Bleomycin 14D, Lane 5-Control, Lane 6-Ladder, Lane 7-Control, Lane 8Bleomycin 7D

(B)

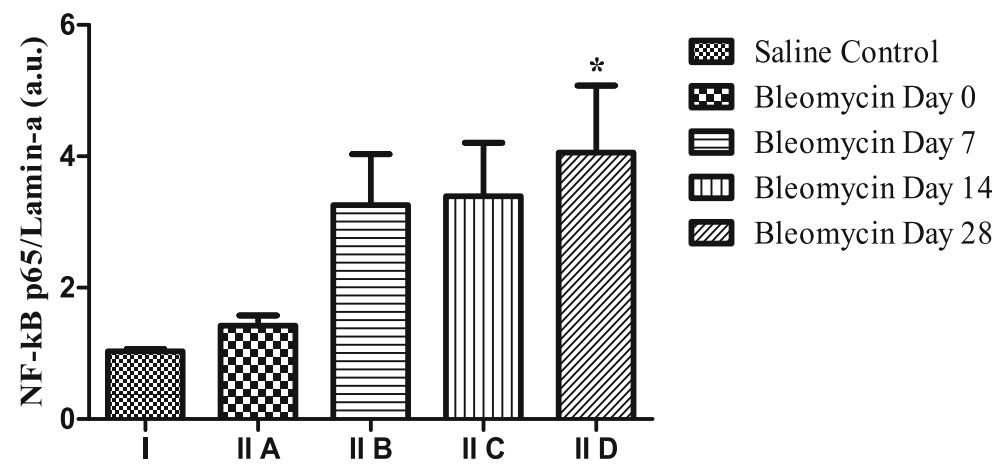

Fig. 5 a NF-kB p65/Lamin-A/C expression before and after bleomycin treatment. An upregulation of NF-kB p65 expression is seen on day 7 after bleomycin instillation that persists up to day 14 and further increases on day 28, compared to control. $\mathbf{b}$ Densitometric analysis of the NF-KB p65 and Lamin-A/C (74 kDa and $65 \mathrm{kDa}$ respectively) protein bands shows significant upregulation of NF-KB p65 protein expression from day 7 onwards up to day $28 .{ }^{* *} p<0.001$ group II C, D vs. group I; ${ }^{*} p<0.05$ group II B vs group I

[86]. Thereby suggesting that NF-кB induced by LMWHA fragments and TLR-2,4 promotes fibrosis by orchestrating local inflammatory reactions and altering protease-antiprotease balance maintaining the fibrotic responses [87].

\section{Discussion}

The pathogenesis of bleomycin-induced pneumonitis is associated with multiple mechanisms, including oxidative damage, protease-antiprotease imbalance [38], caveolin deficiency [78], TGF- $\beta 1$ [69], and genetic susceptibility [88]. Initially, the ECM was considered to be a simple scaffold providing structural support to lung airways. However, recently, the ECM components have been observed to be a major determinant of cell behavior, fate, and function [37].

In the present study, we elaborate on the dynamic role of ECM and LMW-HA fragments in regulating the epithelial injury/repair processes. In the early phase, LMW-HA alerts the immune system of a breach in tissue integrity [23] and activates TLR-2,4, alveolar macrophages, and NF- $\mathrm{BB}$ signalling, resulting in inflammation. TLR-4 mRNA subsequently downregulates and shifts the TLR-2/TLR-4 balance to more than 1 . This predisposes to the progression of inflammation to fibrosis $[14,80,89]$ and results in a progressive increase in lung hydroxyproline levels [86]. Thus, the ECM-driven LMW-HA-TLR-2,4-NF-kB 
pathway defines the extent of cellular macrophage infiltration and parenchymal matrix remodelling. They are reflective of the state of tissue integrity and may serve as biomarker of active fibrosis in chronic lung diseases and as potential therapeutic targets.

In 2020, efforts have been made to understand the pathophysiology of the novel coronavirus patients who are predisposed to develop chronic lung disease following COVID-19. These patients have lung inflammation with activation of NF-kappa B (NF- $\mathrm{kB})$ transcription factor, in lung macrophages [90], release of inflammatory cytokines (IL-1 $\beta, 6$, TNF- $\alpha$ ), induction of HA synthase 2 in lung AEC, endothelium and fibroblasts, accumulation of prominent hyaluronan exudates in the alveolar spaces, and progression to acute respiratory distress syndrome, [7]. High molecular weight HA predominates in most tissues under healthy conditions, whereas fragmented low molecular weight HA polymers predominate at sites of active inflammation [91], thereby suggesting that adjuvant treatment targeting hyaluronan, such as intranasal administration of exogenous hyaluronidase or HA inhibitor (4-methylumbelliferone (4-MU) [60] may be a promising approach to reduce mortality in critically ill covid-19 patients [7]. Similarly, the immunomodulation of NF-кB activation and inhibitions of NF-кB (ІкB) degradation may result in a reduction of the cytokine storm and have been suggested as a potential therapeutic target for severe COVID-19 [90].

The strong binding of the SARS-COV-2 spike protein with Toll-like receptors-1,4,6 and especially with TLR-4 causes an intense exacerbation of the host immune response with release of interleukin-6 (IL-6) and tumor necrosis factor-alpha (TNF- $\alpha$ ), and enhanced severity of COVID-19 pathology [73]. The TLRs are pattern recognition receptors which recognize pathogen-associated molecular patterns (PAMPs) as well as endogenous DAMPs such as hyaluronan and trigger the innate immune response [92]. TLR-4 activation kills the microbes but can cause DAMP associated host tissue damage as has been previously reported [93, 94]. Tissue damage is initiated by the myeloid differentiating primary response gene 88 (MyD88)-dependent or the MyD88independent pathways [95] leading to macrophage, natural killer cell, mast cell recruitment and their release of several interleukins, interferons, reactive oxygenspecies (ROS), and reactive nitrogen species (RNS) [96]. Moreover, the TLR4-NF-kB pathway is central towards promoting infection-induced lung injury in aging patients with comorbidities such as diabetes, atherosclerosis, obesity, and hypertension, thus suggesting the utility of therapeutic targeting of TLR-4 pathway by compounds such as statins, ACE inhibitors, opioids, and steroids in COVID-19 [73].

\section{Conclusions}

The lung parenchymal hyaluronan fragments and TLR2/ TLR4 balance form the critical link between AEC apoptosis [14], activation of innate immune response, and development of cytokine storm, inflammation, and lung fibrosis in both infectious and non-infectious lung injury. The LMW-HA-TLR-2,4-NF-kB pathway should be explored as a biomarker and for its therapeutic potential, in controlling the severity of lung inflammation and its progression to lung fibrosis.

\section{Abbreviations \\ PF: Pulmonary fibrosis; SARS-CoV-2: Severe acute respiratory syndrome coronavirus 2; ECM: Extracellular matrix; LMW-HA: LMW-hyaluronan; \\ DAMP: Damage-associated molecular patterns; TLR: Toll-like receptor; NF- kb: Nuclear factor-kappa B; AECs: Alveolar epithelial cells; EMT: Epithelial- mesenchymal transition; IL: Interleukins; TNF: Tumor necrosis factor; HAS2: HA synthase 2; DAD: Diffuse alveolar damage; ARDS: Acute respiratory distress syndrome; MMP: Matrix metalloproteinases; IRAK-1: IL-1R-associated kinase 1; TRAF: TNF receptor-associated factor; JNKs: Jun N-terminal kinases; MAPKs: Mitogen-activated protein kinases; TGF- $\beta 1$ : Transforming growth factor- $\beta$ 1; PDGF-1: Platelet-derived growth factor-1; MIP-1: Macrophage inflammatory protein-1}

\section{Acknowledgements}

The authors gratefully acknowledge the Department of Science and Technology, India, for extramural Grant (2010) and University Grants Commission for Research fellowship awarded to Ms. Apoorva Pandey (UGC NET JRF 2011) for carrying out the above research work.

\section{Authors' contributions}

AP performed the animal experiments and molecular studies. RK analyzed and interpreted all the data regarding the histological examination and molecular results. SK was a major contributor in writing the manuscript. All authors read and approved the final manuscript.

\section{Funding}

Department of Science and Technology, India-funding for consumables and research staff.

University Grants Commission, India_-funding for research staff.

Availability of data and materials

Not applicable

\section{Declarations}

\section{Ethics approval and consent to participate}

Approval of Institutional animal ethical committee has been obtained: vide letter No-IAEC/41/2014 dated 03/09/2014.

\section{Consent for publication}

Not applicable

\section{Competing interests}

The authors declare that they have no competing interests.

\section{Author details}

'Deparment of Pathology, V.P. Chest Institute, University of Delhi, Delhi 110007, India. ${ }^{2}$ Department of Biochemistry, V.P. Chest Institute, University of Delhi, Delhi 110007, India.

Received: 17 March 2021 Accepted: 11 May 2021

Published online: 21 May 2021

\section{References}

1. Rosenbloom J, Mendoza FA, Jimenez SA (1832) Strategies for anti-fibrotic therapies. Biochim Biophys Acta Mol basis Dis 2013:1088-1103 
2. Wilkinson TS, Potter-Perigo S, Tsoi C, Altman LC, Wight TN (2004) Pro-and anti-inflammatory factors cooperate to control hyaluronan synthesis in lung fibroblasts. Am J Respir Cell Mol Biol 31(1):92-99. https://doi.org/10.1165/ rcmb.2003-03800C

3. Vasarmidi E, Tsitoura E, Spandidos DA, Tzanakis N, Antoniou KM (2020) Pulmonary fibrosis in the aftermath of the COVID-19 era. Exp Ther Med 20(3):2557-2560. https://doi.org/10.3892/etm.2020.8980

4. Laurent TC, Laurent UB, Fraser JR (1996) The structure and function of hyaluronan: an overview. Immunol Cell Biol 74(2):a1-a7. https://doi.org/10.1 038/icb.1996.32

5. Kaber G, Kratochvil MJ, Burgener EB, Peltan EL, Barlow G, Yang S, Nicolls MR, de Jesus Perez V, Rosser JI, Wardle AJ, Kalinowski A (2020) Hyaluronan is abundant in COVID-19 respiratory secretions. medRxiv [Preprint]. 11:2020.09. 11.20191692. https://doi.org/10.1101/2020.09.11.20191692.

6. Ding M, Zhang Q, Li Q, Wu T, Huang YZ (2020) Correlation analysis of the severity and clinical prognosis of 32 cases of patients with COVID-19. Respir Med 167:105981. https://doi.org/10.1016/j.rmed.2020.105981

7. Hellman U, Karlsson MG, Engström-Laurent A, Cajander S, Dorofte L, AhIm C, Laurent C, Blomberg A (2020) Presence of hyaluronan in lung alveoli in severe Covid-19: an opening for new treatment options? J Biol Chem 295(45):15418-15422. https://doi.org/10.1074/jbc.AC120.015967

8. Wight TN, Potter-Perigo S (2011) The extracellular matrix: an active or passive player in fibrosis? Am J Physiol Gastrointest Liver Physiol 301 (6): G950-G955. https://doi.org/10.1152/ajpgi.00132.2011

9. Kim HS, Go H, Akira S, Chung DH (2011) TLR2-mediated production of IL-27 and chemokines by respiratory epithelial cells promotes bleomycin-induced pulmonary fibrosis in mice. J Immunol 187(8):4007-4017. https://doi.org/1 0.4049/jimmunol.1101654

10. Girish KS, Kemparaju K (2007) The magic glue hyaluronan and its eraser hyaluronidase: a biological overview. Life Sci 80(21):1921-1943. https://doi. org/10.1016/j.lfs.2007.02.037

11. Šoltés L, Mendichi R, Kogan G, Schiller J, Stankovska M, Arnhold J (2006) Degradative action of reactive oxygen species on hyaluronan. Biomacromolecules. 7(3):659-668. https://doi.org/10.1021/bm050867v

12. Albeiroti S, Soroosh A, de la Motte CA (2015) Hyaluronan's role in fibrosis: a pathogenic factor or a passive player? Biomed Res Int 25:2015

13. Ebihara T, Venkatesan N, Tanaka R, Ludwig MS (2000) Changes in extracellular matrix and tissue viscoelasticity in bleomycin-induced lung fibrosis: temporal aspects. Am J Respir Crit Care Med 162(4):1569-1576. https://doi.org/10.1164/ajrccm.162.4.9912011

14. Jiang D, Liang J, Fan J, Yu S, Chen S, Luo Y, Prestwich GD, Mascarenhas MM, Garg HG, Quinn DA, Homer RJ (2005) Regulation of lung injury and repair by Toll-like receptors and hyaluronan. Nat Med 11(11):1173-1179. https:// doi.org/10.1038/nm1315

15. Weigel JA, Raymond RC, Weigel PH (2002) The hyaluronan receptor for endocytosis (HARE) is not CD44 or CD54 (ICAM-1). Biochem Biophys Res Commun 294(4):918-922. https://doi.org/10.1016/50006-291X(02)00558-2

16. Hardwick C, Hoare K, Owens R, Hohn HP, Hook M, Moore D, Cripps V, Austen L, Nance DM, Turley EA (1992) Molecular cloning of a novel hyaluronan receptor that mediates tumor cell motility. J Cell Biol 117(6): 1343-1350. https://doi.org/10.1083/jcb.117.6.1343

17. Termeer C, Benedix F, Sleeman J, Fieber C, Voith U, Ahrens T, Miyake K, Freudenberg M, Galanos C, Simon JC (2002) Oligosaccharides of Hyaluronan activate dendritic cells via toll-like receptor 4. J Exp Med 195(1):99-111. https://doi.org/10.1084/jem.20001858

18. Tolg C, McCarthy JB, Yazdani A, Turley EA (2014) Hyaluronan and RHAMM in wound repair and the "cancerization" of stromal tissues. Biomed Res Int 2014:1-18. https://doi.org/10.1155/2014/103923

19. Cyphert JM, Trempus CS, Garantziotis S (2015) Size matters: molecular weight specificity of hyaluronan effects in cell biology. Int J Cell Biol 2015:18. https://doi.org/10.1155/2015/563818

20. Schaefer $L$ (2014) Complexity of danger: the diverse nature of damageassociated molecular patterns. J Biol Chem 289(51):35237-35245. https://doi. org/10.1074/jbc.R114.619304

21. Ruppert SM, Hawn TR, Arrigoni A, Wight TN, Bollyky PL (2014) Tissue integrity signals communicated by high-molecular weight hyaluronan and the resolution of inflammation. Immunol Res 58(2-3):186-192. https://doi. org/10.1007/s12026-014-8495-2

22. Stern R, Asari AA, Sugahara KN (2006) Hyaluronan fragments: an information-rich system. Eur J Cell Biol 85(8):699-715. https://doi.org/10.101 6/j.ejcb.2006.05.009
23. Johnson P, Arif AA, Lee-Sayer SS, Dong Y (2018) Hyaluronan and its interactions with immune cells in the healthy and inflamed lung. Front Immunol 9:2787. https://doi.org/10.3389/fimmu.2018.02787

24. Esposito AJ, Bhatraju PK, Stapleton RD, Wurfel MM, Mikacenic C (2017) Hyaluronic acid is associated with organ dysfunction in acute respiratory distress syndrome. Crit Care 21(1):1-8

25. Bray BA, Sampson PM, Osman M, Giandomenico A, Turino GM (1991) Early changes in lung tissue hyaluronan (hyaluronic acid) and hyaluronidase in bleomycin-induced alveolitis in hamsters. Am Rev Respir Dis 143(2):284-288. https://doi.org/10.1164/ajrccm/143.2.284

26. Campo GM, Avenoso A, Campo S, d'Ascola A, Nastasi G, Calatroni A (2010) Small hyaluronan oligosaccharides induce inflammation by engaging both toll-like-4 and CD44 receptors in human chondrocytes. Biochem Pharmacol 80(4):480-490. https://doi.org/10.1016/j.bcp.2010.04.024

27. Yamawaki H, Hirohata S, Miyoshi T, Takahashi K, Ogawa H, Shinohata R, Demircan K, Kusachi S, Yamamoto K, Ninomiya Y (2009 Jan 1) Hyaluronan receptors involved in cytokine induction in monocytes. Glycobiology. 19(1): 83-92. https://doi.org/10.1093/glycob/cwn109

28. Scheibner KA, Lutz MA, Boodoo S, Fenton MJ, Powell JD, Horton MR (2006) Hyaluronan fragments act as an endogenous danger signal by engaging TLR2. J Immunol 177(2):1272-1281. https://doi.org/10.4049/jimmunol.1 77.2.1272

29. McKee CM, Penno MB, Cowman M, Burdick MD, Strieter RM, Bao C, Noble PW (1996) Hyaluronan (HA) fragments induce chemokine gene expression in alveolar macrophages. The role of HA size and CD44. J Clin Investig 98(10):2403-2413. https://doi.org/10.1172/JCl119054

30. Taylor KR, Yamasaki K, Radek KA, Di Nardo A, Goodarzi H, Golenbock D, Beutler B, Gallo RL (2007) Recognition of hyaluronan released in sterile injury involves a unique receptor complex dependent on Toll-like receptor 4, CD44, and MD-2. J Biol Chem 282(25):18265-18275. https://doi.org/10.1 074/jbc.M606352200

31. Gaggar A, Weathington N (2016) Bioactive extracellular matrix fragments in lung health and disease. J Clin Investig 126(9):3176-3184. https://doi.org/1 $0.1172 / J C l 83147$

32. Collins SL, Black KE, Chan-Li Y, Ahn YH, Cole PA, Powell JD, Horton MR (2011) Hyaluronan fragments promote inflammation by down-regulating the anti-inflammatory A2a receptor. Am J Respir Cell Mol Biol 45(4):675-683

33. Haitsma JJ, Uhlig S, Lachmann U, Verbrugge SJ, Poelma DL, Lachmann B (2002) Exogenous surfactant reduces ventilator-induced decompartmentalization of tumor necrosis factor a in absence of positive end-expiratory pressure. Intensive Care Med 28(8):1131-1137. https://doi. org/10.1007/s00134-002-1377-4

34. Liang J, Zhang Y, Xie T, Liu N, Chen H, Geng Y, Kurkciyan A, Mena JM, Stripp BR, Jiang D, Noble PW (2016) Hyaluronan and TLR4 promote surfactantprotein-C-positive alveolar progenitor cell renewal and prevent severe pulmonary fibrosis in mice. Nat Med 22(11):1285-1293. https://doi.org/10.1 038/nm.4192

35. Parker MW, Rossi D, Peterson M, Smith K, Sikström K, White ES, Connett JE, Henke CA, Larsson O, Bitterman PB (2014) Fibrotic extracellular matrix activates a profibrotic positive feedback loop. J Clin Investig 124(4):1622-1635

36. Philp CJ, Siebeke I, Clements D, Miller S, Habgood A, John AE, Navaratnam V, Hubbard RB, Jenkins G, Johnson SR (2018) Extracellular matrix crosslinking enhances fibroblast growth and protects against matrix proteolysis in lung fibrosis. Am J Respir Cell Mol Biol 58(5):594-603. https://doi.org/1 $0.1165 / \mathrm{rcmb} .2016-03790 \mathrm{C}$

37. Tomos IP, Tzouvelekis A, Aidinis V, Manali ED, Bouros E, Bouros D, Papiris SA (2017) Extracellular matrix remodeling in idiopathic pulmonary fibrosis. It is the 'bed' that counts and not 'the sleepers'. Expert Rev Respir Med 11(4): 299-309. https://doi.org/10.1080/17476348.2017.1300533

38. Nguyen NM, Bai Y, Mochitate K, Senior RM (2002) Laminin a-chain expression and basement membrane formation by MLE-15 respiratory epithelial cells. Am J Phys Lung Cell Mol Phys 282(5):L1004-L1011

39. Serrano-Mollar A, Closa D, Prats N, Blesa S, Martinez-Losa M, Cortijo J, Estrela $J M$, Morcillo EJ, Bulbena O (2003) In vivo antioxidant treatment protects against bleomycin-induced lung damage in rats. Br J Pharmacol 138(6): 1037-1048. https://doi.org/10.1038/sj.bjp.0705138

40. Bradford MM (1976) A rapid and sensitive method for the quantitation of microgram quantities of protein utilizing the principle of protein-dye binding. Anal Biochem 72(1-2):248-254. https://doi.org/10.1016/0003-2 697(76)90527-3 
41. Smiley ST, King JA, Hancock WW (2001) Fibrinogen stimulates macrophage chemokine secretion through toll-like receptor 4. J Immunol 167(5):28872894. https://doi.org/10.4049/jimmunol.167.5.2887

42. Guillot L, Balloy V, McCormack FX, Golenbock DT, Chignard M, Si-Tahar M (2002) Cutting edge: the immunostimulatory activity of the lung surfactant protein-A involves Toll-like receptor 4. J Immunol 168(12):5989-5992. https://doi.org/10.4049/jimmunol.168.12.5989

43. Okamura Y, Watari M, Jerud ES, Young DW, Ishizaka ST, Rose J, Chow JC, Strauss JF III (2001) The extra domain A of fibronectin activates Toll-like receptor 4. J Biol Chem 276(13):10229-10233. https://doi.org/10.1074/jbc.M1 00099200

44. Johnson GB, Brunn GJ, Kodaira Y, Platt JL (2002) Receptor-mediated monitoring of tissue well-being via detection of soluble heparan sulfate by Toll-like receptor 4. J Immunol 168(10):5233-5239. https://doi.org/10.4049/ jimmunol.168.10.5233

45. Park JS, Svetkauskaite D, He Q, Kim JY, Strassheim D, Ishizaka A, Abraham E (2004) Involvement of toll-like receptors 2 and 4 in cellular activation by high mobility group box 1 protein. J Biol Chem 279(9):7370-7377. https:// doi.org/10.1074/jbc.M306793200

46. Tsan MF, Gao B (2004) Endogenous ligands of Toll-like receptors. J Leukoc Biol 76(3):514-519. https://doi.org/10.1189/jlb.0304127

47. Lauer ME, Dweik RA, Garantziotis S, Aronica MA (2015) The rise and fall of hyaluronan in respiratory diseases. Int J Cell Biol 2015:1-15. https://doi.org/1 $0.1155 / 2015 / 712507$

48. Teder P, Vandivier RW, Jiang D, Liang J, Cohn L, Puré E, Henson PM, Noble PW (2002) Resolution of lung inflammation by CD44. Science. 296(5565): 155-158. https://doi.org/10.1126/science.1069659

49. Savani RC, Hou G, Liu P, Wang C, Simons E, Grimm PC, Stern R, Greenberg AH, DeLisser HM, Khalil N (2000) A role for hyaluronan in macrophage accumulation and collagen deposition after bleomycin-induced lung injury. Am J Respir Cell Mol Biol 23(4):475-484. https://doi.org/10.1165/a jrcmb.23.4.3944

50. Tavianatou AG, Caon I, Franchi M, Piperigkou Z, Galesso D, Karamanos NK (2019) Hyaluronan: molecular size-dependent signaling and biological functions in inflammation and cancer. FEBS J 286(15):2883-2908. https://doi. org/10.1111/febs.14777

51. Petrey AC, de la Motte CA (2014) Hyaluronan, a crucial regulator of inflammation. Front Immunol 11:101

52. Avenoso A, Bruschetta G, D'Ascola A, Scuruchi M, Mandraffino G, Gullace R, Saitta A, Campo S, Campo GM (2019) Hyaluronan fragments produced during tissue injury: a signal amplifying the inflammatory response. Arch Biochem Biophys 663:228-238. https://doi.org/10.1016/j.abb.2019.01.015

53. Moore BB, Lawson WE, Oury TD, Sisson TH, Raghavendran K, Hogaboam CM (2013) Animal models of fibrotic lung disease. Am J Respir Cell Mol Biol 49: 167-179

54. Singer SJ, Kupfer A (1986) The directed migration of eukaryotic cells. Annu Rev Cell Biol 2(1):337-365. https://doi.org/10.1146/annurev.cb.02.110186.002005

55. Gerdin B, Hällgren R (1997) Dynamic role of hyaluronan (HYA) in connective tissue activation and inflammation. J Intern Med 242(1):49-55. https://doi. org/10.1046/j.1365-2796.1997.00173.x

56. Jarman ER, Khambata VS, Li YY, Cheung K, Thomas M, Duggan N, Jarai G (2014) A translational preclinical model of interstitial pulmonary fibrosis and pulmonary hypertension: mechanistic pathways driving disease pathophysiology. Physiol Rep 2(9):e12133. https://doi.org/10.14814/ phy2.12133

57. Gibbons MA, MacKinnon AC, Ramachandran P, Dhaliwal K, Duffin R, Phythian-Adams AT, van Rooijen N, Haslett C, Howie SE, Simpson AJ, Hirani N (2011) Ly6Chi monocytes direct alternatively activated profibrotic macrophage regulation of lung fibrosis. Am J Respir Crit Care Med 184(5): 569-581. https://doi.org/10.1164/rccm.201010-17190C

58. Beutler B (2007) Neo-ligands for innate immune receptors and the etiology of sterile inflammatory disease. Immunol Rev 220(1):113-128. https://doi. org/10.1111/j.1600-065X.2007.00577.x

59. Kulshrestha R, Pandey A, Jaggi A, Bansal S (2020) Beneficial effects of Nacetylcysteine on protease-antiprotease balance in attenuating bleomycininduced pulmonary fibrosis in rats. Iran J Basic Med Sci 23:396

60. Shi Y, Wang Y, Shao C, Huang J, Gan J, Huang X, Bucci E, Piacentini M, Ippolito G, Melino G (2020) COVID-19 infection: the perspectives on immune responses. Cell Death Differ 27(5):1451-1454

61. Blanco-Melo D, Nilsson-Payant BE, Liu WC, Uhl S, Hoagland D, Møller R, Jordan TX, Oishi K, Panis M, Sachs D, Wang TT (2020) Imbalanced host response to SARS-CoV-2 drives development of COVID-19. Cell. 181(5):10361045. https://doi.org/10.1016/j.cell.2020.04.026

62. Lee-Sayer SS, Dong Y, Arif AA, Olsson M, Brown KL, Johnson P (2015) The where, when, how, and why of hyaluronan binding by immune cells. Front. Immunol. 6:150

63. O'Neill LA (2005) TLRs play good cop, bad cop in the lung. Nat Med 11(11): 1161-1162. https://doi.org/10.1038/nm1105-1161

64. Liu J, Guan X, Ma X (2007) Regulation of IL-27 p28 gene expression in macrophages through MyD88-and interferon- $\gamma$-mediated pathways. J Exp Med 204(1):141-152. https://doi.org/10.1084/jem.20061440

65. Basu S, Fenton MJ (2004) Toll-like receptors: function and roles in lung disease. AJP Lung Cell Mol Physiol 286(5):L887-L892. https://doi.org/10.11 52/ajplung.00323.2003

66. Yang HZ, Cui B, Liu HZ, Chen ZR, Yan HM, Hua F, Hu ZW (2009) Targeting TLR2 attenuates pulmonary inflammation and fibrosis by reversion of suppressive immune microenvironment. J Immunol 182(1):692-702. https:// doi.org/10.4049/jimmunol.182.1.692

67. Wermuth PJ, Jimenez SA (2015) The significance of macrophage polarization subtypes for animal models of tissue fibrosis and human fibrotic diseases. Clin Transl Med 4:1-9

68. Frey H, Schroeder N, Manon-Jensen T, lozzo RV, Schaefer L (2013) Biological interplay between proteoglycans and their innate immune receptors in inflammation. FEBS J 280(10):2165-2179. https://doi.org/1 $0.1111 /$ febs. 12145

69. Kotarkonda LK, Kulshrestha R, Ravi K (2017) Role of insulin like growth factor axis in the bleomycin induced lung injury in rats. Exp Mol Pathol 102:86-96

70. Yang D, Chen Q, Su SB, Zhang P, Kurosaka K, Caspi RR, Michalek SM, Rosenberg HF, Zhang N, Oppenheim JJ (2008) Eosinophil-derived neurotoxin acts as an alarmin to activate the TLR2-MyD88 signal pathway in dendritic cells and enhances Th2 immune responses. J Exp Med 205(1): 79-90. https://doi.org/10.1084/jem.20062027

71. Zhao H, Leu SW, Shi L, Dedaj R, Zhao G, Garg HG, Shen L, Lien E, Fitzgerald KA, Shiedlin A, Shen H, Quinn DA, Hales CA (2010) TLR4 is a negative regulator in noninfectious lung inflammation. J Immunol 184(9):5308-5314. https://doi.org/10.4049/jimmunol.1000009

72. Papageorgiou IE, Lewen A, Galow LV, Cesetti T, Scheffel J, Regen T, Hanisch UK, Kann O (2016) TLR4-activated microglia require IFN- $\gamma$ to induce severe neuronal dysfunction and death in situ. Proc Natl Acad Sci 113(1):212-217. https://doi.org/10.1073/pnas.1513853113

73. Brandão SCS, Ramos JOX, Dompieri LT, Godoi ETAM, Figueiredo JL, Sarinho ESC, Chelvanambi S, Aikawa M (2021) Is Toll-like receptor 4 involved in the severity of COVID-19 pathology in patients with cardiometabolic comorbidities? Cytokine Growth Factor Rev 58:102-110. https://doi.org/10.1 016/j.cytogfr.2020.09.002.

74. Gariboldi S, Palazzo M, Zanobbio L, Selleri S, Sommariva M, Sfondrini L, Cavicchini S, Balsari A, Rumio C (2008) Low molecular weight hyaluronic acid increases the self-defense of skin epithelium by induction of betadefensin 2 via TLR2 and TLR4. J Immunol 181(3):2103-2110. https://doi. org/10.4049/jimmunol.181.3.2103

75. Zhang X, Shan P, Qureshi S, Homer R, Medzhitov R, Noble PW, Lee PJ (2005) Cutting edge: TLR4 deficiency confers susceptibility to lethal oxidant lung injury. J Immunol 175(8):4834-4838. https:/doi.org/10.4049/jimmunol.175.8.4834

76. Li XX, Jiang DY, Huang XX, Guo SL, Yuan W, Dai HP (2015) Toll like receptor 4 promotes fibrosis in bleomycin induced lung injury in mice. Genet $\mathrm{Mol}$ Res 14(4):17391-17398. https://doi.org/10.4238/2015.December.21.8

77. Yang HZ, Wang JP, Mi S, Liu HZ, Cui B, Yan HM, Yan J, Li Z, Liu H, Hua F, Lu W, Hu ZW (2012) TLR4 activity is required in the resolution of pulmonary inflammation and fibrosis after acute and chronic lung injury. Am J Pathol 180(1):275-292. https://doi.org/10.1016/j.ajpath.2011.09.019

78. Kulshrestha R, Singh H, Pandey A, Soundarya D, Jaggi AS, Ravi K (2020) Differential expression of caveolin-1 during pathogenesis of combined pulmonary fibrosis and emphysema: effect of phosphodiesterase-5 inhibitor. BBA-Mol Basis Dis 1866:165802

79. Mirza MK, Yuan J, Gao XP, Garrean S, Brokovych V, Malik AB et al (2010) Caveolin-1 deficiency dampens Toll-Like Receptor-4 signaling through eNOS activation. Am J Pathol 176(5):2344-2351. https://doi.org/10.2353/ajpath.201 0.091088

80. Noble PW, Lake FR, Henson PM, Riches DW (1993) Hyaluronate activation of CD44 induces insulin like growth factor-1 expression by a tumor necrosis factor - alpha - dependent mechanism in murine macrophages. J Clin Invest 91(6):2368-2377. https://doi.org/10.1172/JCl116469 
81. Lafyatis R, Farina A (2012) New insights into the mechanisms of innate immune receptor signalling in fibrosis. Open Rheumatol J 6(1):72-79. https://doi.org/10.2174/1874312901206010072

82. Inayama M, Nishioka Y, Azuma M, Muto S, Aono Y, Makino H, Tani K, Uehara H, Izumi K, Itai A, Sone S (2006) A novel IKB kinase- $\beta$ inhibitor ameliorates bleomycin-induced pulmonary fibrosis in mice. Am J Respir Crit Care Med 173(9):1016-1022. https://doi.org/10.1164/rccm.200506-9470C

83. Alvira CM (2014) Nuclear-factor-kappa-B signaling in lung development and disease: One Pathway, numerous functions. Birth Defects Res A Clin Mol Teratol 100(3):202-216. https://doi.org/10.1002/bdra.23233

84. Agarwal R, Agarwal P (2017) Targeting extracellular matrix remodeling in disease: could resveratrol be a potential candidate? Exp Biol Med 242(4): 374-383. https://doi.org/10.1177/1535370216675065

85. Vellaichamy E, Khurana ML, Fink J, Pandey KN (2005) Involvement of NF-KB / matrix metalloproteinase pathway in cardiac fibrosis of mice lacking guanylyl cyclase / natriuretic peptide receptor A. J Biol Chem 280(19): 19230-19242. https://doi.org/10.1074/jbc.M411373200

86. Kulshrestha R, Dhanda H, Pandey A, Singh A, Rajkumar (2020) Immunopathogenesis and therapeutic potential of macrophage influx in diffuse parenchymal lung diseases. Expt Rev Resp Med 14(9):917-928.

87. Borthwick LA, Barron L, Hart KM, Vannelia KM, Thompson RW, Oland S et al (2016) Macrophages are critical to the maintenance of IL-13- dependent lung inflammation and fibrosis. Mucosal Immunol 9(1):38-55. https://doi. org/10.1038/mi.2015.34

88. Reinert T, Serodio C, Arthur F, Nunes P, Alves A, Scheliga DS (2013) Bleomycin-induced lung injury. J Cancer Res Ther 2013:480608. https://doi. org/10.1155/2013/480608

89. Horton MR, McKee CM, Bao C, Liao F, Farber JM, Hodge-DuFour J, Pure E, Oliver BL, Wright TM, Noble PW (1998) Hyaluronan fragments synergize with interferon-gamma to induce the C-X-C chemokines mig and interferon-inducible protein-10 in mouse macrophages. J Biol Chem 273(52): 35088-35094. https://doi.org/10.1074/jbc.273.52.35088

90. Hariharan A, Hakeem AR, Radhakrishnan S, Reddy MS, Rela M (2021) The role and therapeutic potential of NF-kappa-B pathway in severe COVID-19 patients. Inflammopharmacology. 1:91-100

91. Nagy N, Kuipers HF, Frymoyer AR, Ishak HD, Bollyky JB, Wight TN et al (2015) L. 4-methylumbelliferone treatment and hyaluronan inhibition as a therapeutic strategy in inflammation, autoimmunity, and cancer. Front Immunol 6:123

92. Jeong E, Lee JY (2011) Intrinsic and extrinsic regulation of innate immune receptors. Yonsei Med J 52(3):379-392. https://doi.org/10.3349/ymj.2011. 52.3.379

93. Okun E, Griffioen KJ, Lathia JD, Tang SC, Mattson MP, Arumugam TV (2009) Toll-like receptors in neurodegeneration. Brain Res Rev 59:27-292

94. Kaisho T, Akira S (2002) Toll-like receptors as adjuvant receptors. Biochim Biophys Acta 1589(1):1-13. https://doi.org/10.1016/S0167-4889(01)00182-3

95. Kawasaki K, Akashi S, Shimazu R, Yoshida T, Miyake K, Nishijima M (2000) Mouse toll-like receptor 4.MD-2 complex mediates lipopolysaccharidemimetic signal transduction by Taxol. J Biol Chem 275(4):2251-2254. https:// doi.org/10.1074/jbc.275.4.2251

96. Lucas K, Maes M (2013) Role of the toll like receptor (TLR) radical cycle in chronic inflammation: possible treatments targeting the TLR4 pathway. Mol Neurobiol 48(1):190-204. https://doi.org/10.1007/s12035-013-8425-7

\section{Publisher's Note}

Springer Nature remains neutral with regard to jurisdictional claims in published maps and institutional affiliations.

\section{Submit your manuscript to a SpringerOpen ${ }^{\circ}$ journal and benefit from:}

- Convenient online submission

- Rigorous peer review

- Open access: articles freely available online

High visibility within the field

- Retaining the copyright to your article

Submit your next manuscript at $\boldsymbol{\nabla}$ springeropen.com 